\title{
Upaya Peningkatan Berat Badan Bayi Usia 6 - 12 Bulan Dengan Baby Massage di Desa Pungging Kecamatan Pungging Mojosari - Mojokerto
}

\author{
Rina Widiyawati*, Titiek Idayanti \\ STIKes Dian Husada Mojokerto, Indonesia \\ *gugik.rina@gmail.com
}

\begin{abstract}
ABSTRAK
Beberapa faktor yang mempengaruhi proses pertumbuhan bayi, baik berat badan maupun tinggi badan diantaranya adalah keturunan dan lingkungan. Faktor keturunan atau genetik ini berhubungan gen yang diberikan dari seseorang ayah dan ibu pada anaknya. Faktor lingkungan (environment) terdiri dari lingkungan biologis, fisik sosial dan psikologis.

Kegiatan pengabdian kepada masyarakat ini dilakukan kepada semua ibu di Desa Pungging yang memiliki bayi usia $6-12$ bulan. Kegiatan ini dilakukan di Balai Desa Pungging Mojosari - Mojokerto. Sebelum kegiatan dimulai, tim penyuluh memberikan kuesioner yang berisi tentang apakah ibu sudah mengetahui baby massage, hal ini dilakukan untuk mengetahui tingkat pengetahuan ibu tentang baby massage. Selanjutnya kegiatan ini dimulai dengan memberikan penyuluhan tentang upaya peningkatan berat badan bayi dengan baby massage. Setelah audiens (ibu-ibu) menerima materi, diadakan sesi tanya jawab bagi ibu - ibu yang masih belum mengerti dan paham tentang baby massage. Setelah itu dilakukan pratikum oleh tim penyuluh dengan metode demonstrasi di depan semua audiens (ibu-ibu) tentang cara melakukan baby massage yang benar agar dapat membantu mengoptimalkan pertumbuhan bayi terutama peningkatan berat badan bayi. Setelah metode demonstrasi selesai, tim penyuluh menunjuk beberapa ibu secara acak untuk mempraktikkan cara melakukan baby massage. Setelah acara selesai dilakukan evaluasi dengan membagikan kuesioner untuk diisi oleh ibu - ibu guna mengetahui sejauh mana keberhasilan kegiatan pengabdian kepada masyarakat yang telah dilakukan.
\end{abstract}

Kata Kunci: Peningkatan Berat Badan Bayi, Baby Massage, Ibu

Received: June 8, 2020

Revised: June 24, 2020

Accepted: July 29, 2020

\section{(i) (2)}

This is an open-acces article distributed under the terms of the Creative Commons Attribution-ShareAlike 4.0 International License.

\section{PENDAHULUAN}

Masa bayi merupakan tahapan dimana pertumbuhan yang sangat cepat, dimulai bayi itu lahir hingga nanti berusia satu tahun. Bayi dianggap sebagai periode kritis dalam pertumbuhan karena merupakan periode dimana dasar-dasar dari awal kehidupannya. Masa bayi dikatakan sebagai golden age atau masa keemasan karena pada masa ini pertumbuhan tubuh berlangsung. Beberapa faktor yang mempengaruhi proses pertumbuhan bayi, baik berat badan maupun tinggi badan diantaranya adalah keturunan dan lingkungan. Faktor 


\section{Journal of Community Engagement in Health}

http://jceh.org

ISSN: 2620-3758 (print); 2620-3766 (online)

https://doi.org/10.30994/jceh.v3i2.60

Vol.3 No.2. Sep 2020. Page.176-179

keturunan atau genetik ini berhubungan gen yang diberikan dari seseorang ayah dan ibu pada anaknya. Faktor lingkungan (environment) terdiri dari lingkungan biologis, fisik sosial dan psikologis.

Menurut WHO (2015) prevalensi bayi yang mempunyai berat badan tidak sesuai dengan usianya menjadi masalah kesehatan masyarakat jika prevalensinya $20 \%$ atau lebih. Karenanya persentase bayi yang mempunyai berat badan yang tidak sesuai dengan usia di Indonesia masih tinggi dan merupakan masalah kesehatan yang harus ditanggulangi.

Orang tua memegang peran penting untuk pertumbuhan dan perkembangan anak hendaknya orang tua meningkatkan pengetahuan dalam memfasilitasi kebutuhan anak salah satunya adalah pemahaman tentang stimulasi yang dapat diberikan pada anak mereka. Sehingga baby massage yang dilakukan oleh orang tua dapat merangsang perkembangan dan pertumbuhan anak sesuai dengan usia mereka. Selain itu informasi dapat dipahami dan dapat memberikan dampak perubahan perilaku pada masyarakat khususnya pada ibu. Untuk mewujudkan hal tersebut, maka kami melakukan kemitraan dengan Kepala Desa Pungging dalam melakukan penyuluhan kesehatan dengan memberikan informasi serta wawasan tentang upaya peningkatan berat badan bayi dengan baby massage dan kita memberikan serta mengajarkan secara demonstrasi bagaimana cara melakukan baby massage yang benar kepada para ibu di Desa Pungging.

Kegiatan Pengabdian Kepada Masyarakat (PKM) ini bertujuan untuk memberikan pengetahuan kepada ibu bagaimana cara merangsang peningkatan berat badan anak dan merangsang perkembangan anak dengan menggunakan stimulasi baby massage.

\section{METODE}

1. Survey lapangan

Survey lapangan bertujuan untuk mengamati situasi dan keadaan masyarakat di Desa Pungging, yang direncanakan sebagai sasaran kegiatan pengabdian kepada masyarakat

2. Menetukan sasaran

Sasaran kegiatan pengabdian kepada masyarakat ini adalah semua ibu di Desa

Pungging yang memiliki bayi usia $6-12$ bulan

3. Koordinasi

Berkoordinasi dengan pihak perangkat desa untuk menentukan kesepakatan mufakat tentang waktu dan tempat dilakukan kegiatan penyuluhan.

4. Sosialisai kegiatan

Sosialisasi kegiatan bertujuan untuk memberikan informasi kepada masyarakat tentang waktu dan tempat pelaksanaan kegiatan.

5. Pelaksanaan kegiatan

Kegiatan dilakukan di Balai Desa Pungging Mojosari - Mojokerto. Sasaran atau audiens pada kegiatan ini adalah semua ibu di desa Pungging yang memiliki bayi usia 6 - 12 bulan sejumlah 23 ibu. Kegiatan dimulai pada pagi hari pukul 09.00 WIB. Kegiatan dimulai dengan memberikan kuesioner yang berisi pertanyaan tentang baby massage untuk di jawab oleh ibu - ibu (audiens dalam penyuluhan) yang berguna untuk tolak ukut tim penyuluh dalam mengetahui seberapa banyak ibu yang sudah mengetahui tentang baby massage. Setelah kuesioner selesai diisi oleh audiens, tim penyuluh mulai memberikan materi secara ceramah tentang upaya peningkatan berat badan bayi dengan baby massage. Kemudian kegiatan dilanjutkan dengan sesi tanya jawab, bagi ibu - ibu yang belum mengerti atau paham tentang materi yang disampaikan bisa mengajukan pertanyaan. Setelah acara penyuluhan pemberian materi selesai kemudian dilanjut dengan pratikum secara demonstrasi didepan olehtim 


\section{Journal of Community Engagement in Health}

http://jceh.org

ISSN: $2620-3758$ (print); 2620-3766 (online)

https://doi.org/10.30994/jceh.v3i2.60

Vol.3 No.2. Sep 2020. Page.176-179

penyuluh tentang cara melakukan baby massage yang benar pada bayi. Setelah tim penyuluh melakukan demonstrasi, secara acak tim penyuluh menunjuk beberapa ibu untuk maju kedepan mempraktikkan cara melakukan baby massage yang benar. Hal ini dilakukan bertujuan untuk mengevaluasi apakah kegiatan penyuluhan ini berhasil dan dapat diterima serta di praktikkan oleh ibu ataukah tidak.

\section{HASIL}

Dari pembagian kuesioner yang dilakukan di awal sebelum kegiatan penyuluhan berlangsung, didapatkan hasil 7 ibu mengetahui tentang baby massage dan 16 ibu lainnya masih belum mengetahui dan paham tentang baby massage. Evaluasi yang dilakukan pada pemanggilan ibu secara acak untuk mempraktikkan cara melakukan baby massage didapatkan hasil dari $10 \mathrm{ibu}$ yang dipanggil terdapat $3 \mathrm{ibu}$ yang tidak bisa melakukan baby massage dengan sempurna dan 7 selebihnya mereka dapat melakukan baby massage dengan urutan yang benar. Sedangkan hasil kuesioner evaluasi kegiatan yang dibagikan diakhir didapatkan hasil hampir $100 \%$ semua ibu dapat menjawab semua pertanyaan dengan benar.

Kegiatan ini secara garis besar menunjukkan hasil yang menggembirakan yaitu hampir $100 \% \mathrm{ibu}$ - ibu merespon positif dalam hal kemanfaatan yang sangat tinggi.

\section{PEMBAHASAN}

Dari 23 audiens (ibu - ibu) yang hadir dalam kegiatan pengabdian kepada masyarakat yang dilakukan di Bali Desa Pungging ini, sebagian besar pendidikan terakhir ibu adalah SMP, hal ini mempengaruhi pada kemampuan ibu dalam memahami tentang stimulasi apa saja yang seharusnya dapat dilakukan ibu dalam menunjang pertumbuhan dan perkembangan bayi terutama dalam hal peningkatan berat badan.

Peran orang tua memang sangat penting dalam menunjang pertumbuhan dan perkembangan bayi. Jika pengetahuan orang tua kurang maka hal tersebut juga dapat berpengaruh kepada pemberian stimulasi maupun asupan zat gizi kepada anaknya yang nantinya dapat berpengaruh pada gangguan pertumbuhan dan perkembangan anak.

Dalam kegiatan pengabdian kepada masyarakat ini dilakukan penyuluhan tentang upaya peningkatan berat badan bayi dengan baby massage dan dilakukan demonstrasi cara melakukan baby massage yang benar pada bayi. Evaluasi kegiatan yang didapatkan adalah kegiatan berjalan dengan lancar, peserta antusias dengan aktif mengajukan pertanyaan dan peserta mengikuti kegiatan dengan tertib sampai akhir acara. Dari kegiatan yang sudah dilakukan peserta dapat mengetahui bahwa baby massage dapat menunjang peningkatan berat badan bayi.

\section{KESIMPULAN}

Keberhasilan dari kegiatan ini diharapkan membuat semua ibu yang memiliki anak bayi usia 6 - 12 bulan dapat mengaplikasikan ilmu yang didapat yaitu tentang baby massage. Kegiatan baby massage dapat dilakukan setiap hari secara rutin dirumah masing-masing sehingga pada kunjungan Posyandu setiap bulan dapat terlihat adanya peningkatan berat badan bayi dan tertulis di buku KIA anak.

\section{UCAPAN TERIMA KASIH}

Ucapan terima kasih kami sampaikan kepada seluruh pihak yang terlibat dan membantu terselenggaranya kegiatan pengabdian kepada masyarakat ini sehingga berjalan dengan lancar sesuai dengan yang kita harapkan. Terima kasih kami sampaikan kepada seluruh 


\section{Journal of Community Engagement in Health}

http://jceh.org

pihak Desa Pungging yaitu Bapak Kepala Desa Pungging, segenap Perangkat Desa yang membantu menyediakan tempat dan fasilitasnya untuk kegiatan ini, segenap Kader Desa Pungging dan seluruh ibu yang memiliki bayi usia 6-12 bulan di Desa Pungging yang telah bersedia meluangkan waktunya untuk mengikuti kegiatan pengabdian masyarakat ini.

\section{DAFTAR PUSTAKA}

Andrews. J, (2008), Elite Massage Therapy, Madison Ave, San Diego.

Aurelia. (2011). Tips Pemijatan Pada Bayi. Yogyakarta : Trimedia

Dewi, N.N. Dkk (2010). Effect of massage stimulation on weight gain in full term infants. Paediatrica Indonesiana, 51, 202-206.

Dewi, Siska. (2013). Pijat dan Asupan Gizi Tepat. Yogyakarta : Pustaka Baru Press

Novitasari. (2012).Teori Pijat Bayi - Tingkat pengetahuan ibu tentang pijat bayi di dukuh cemetuk desa lorogtawangsari sukoharjo Tahun 2012.

Santi Enidya. (2012). Buku Pintar Pijat Bayi Untuk Tumbuh Kembang Optimal Sehat \& Cerdas. Yogyakarta : Pinang Mera 